

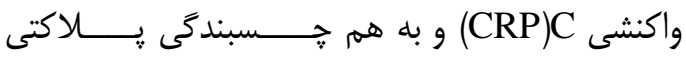

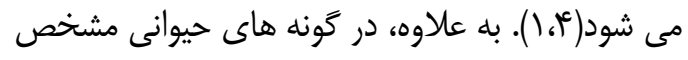

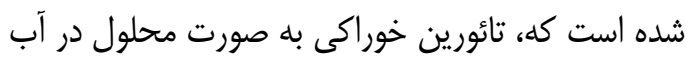

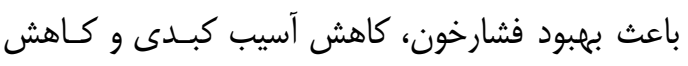

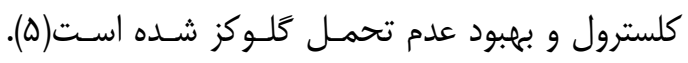

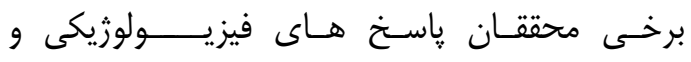

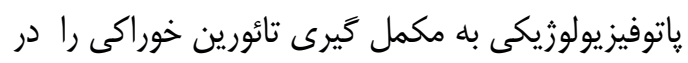

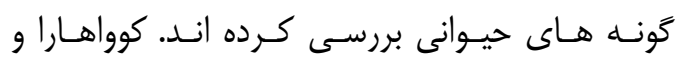

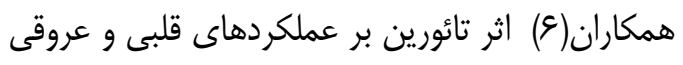

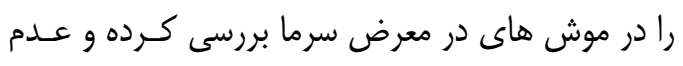

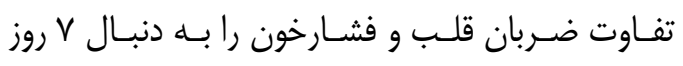

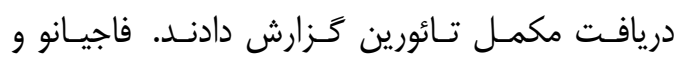
همكاران نيز در يزوهشى اثر ضد يرفشار خونى تائورين

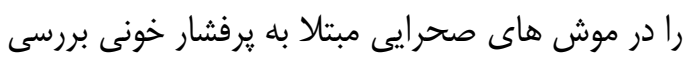

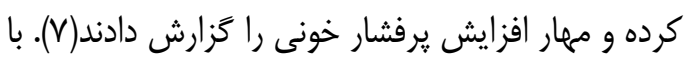

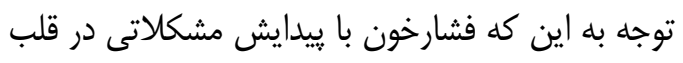

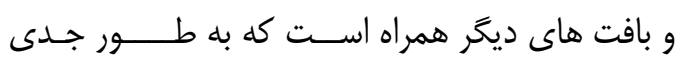

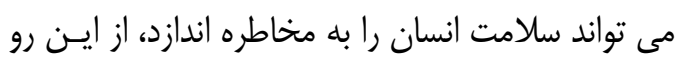

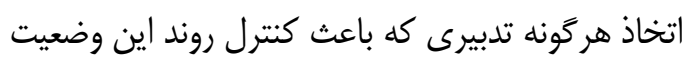

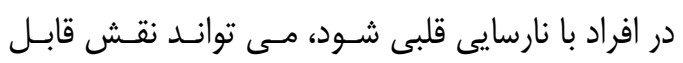

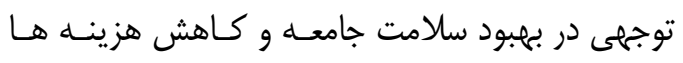

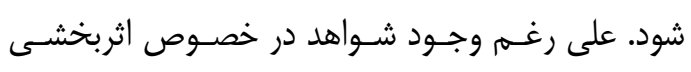

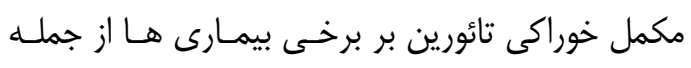

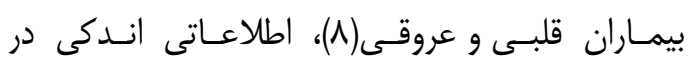

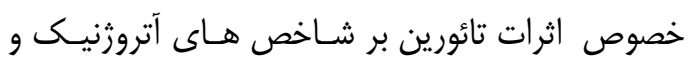

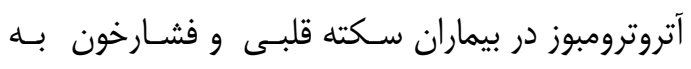

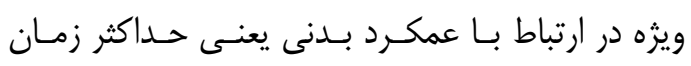

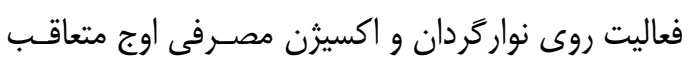

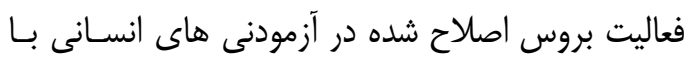

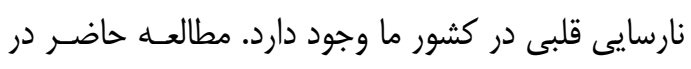

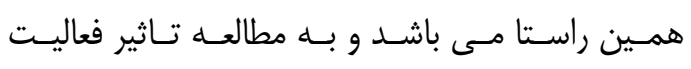

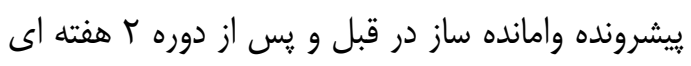

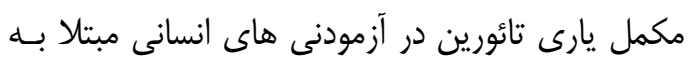

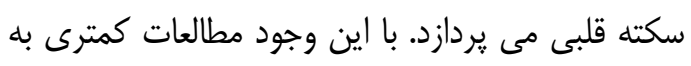

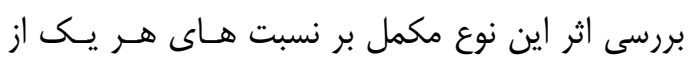

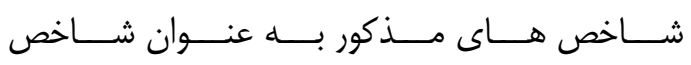

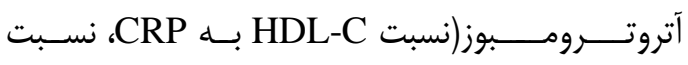

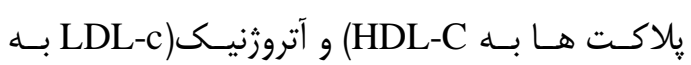

مقدمه بيمارى هاى قلبى و عروقى شايع ترين علت مـرى و و

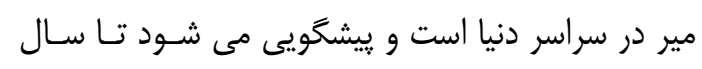

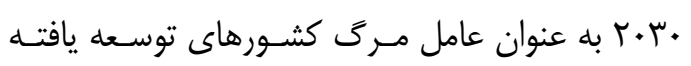

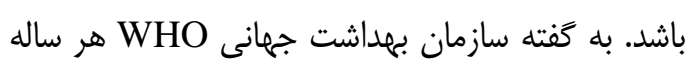

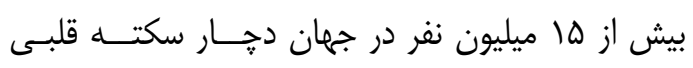

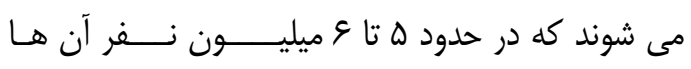

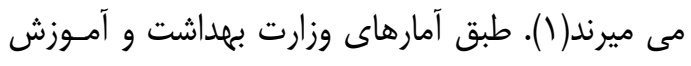

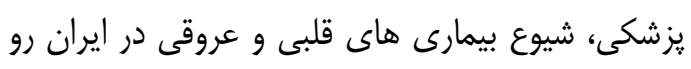
به افزايش است و بـه عنوان اولين عامل مرك ايرانيـان

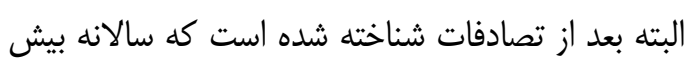

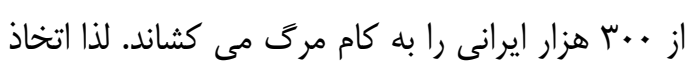

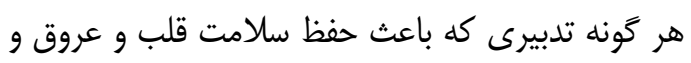

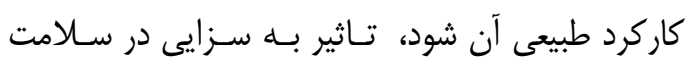

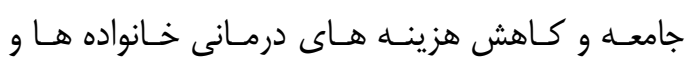

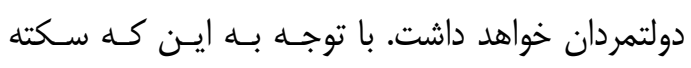

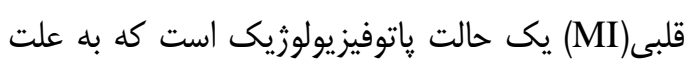

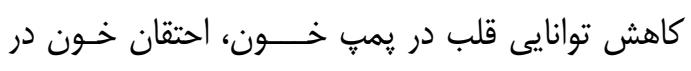

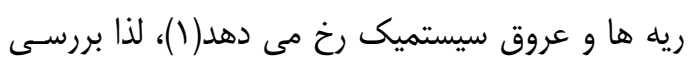

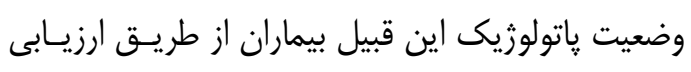

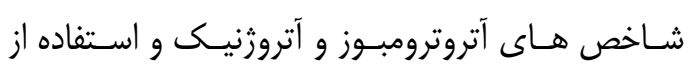

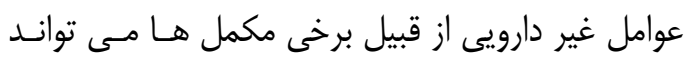
كمك شايانى به بهبود عملكرد قلبى در اين افراد نمايد.

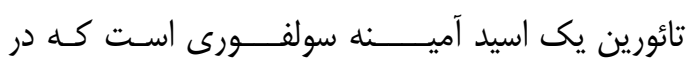

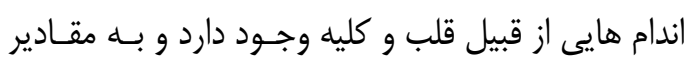

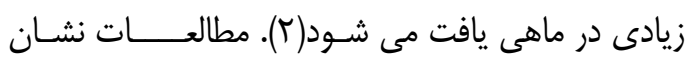

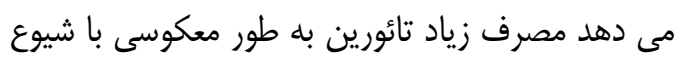
بيمارى كرونرى قلب وكاهش مقاومت انسولين همـراه

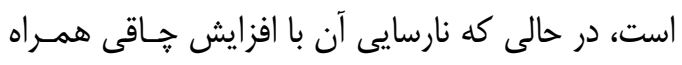

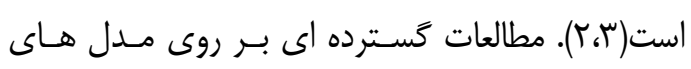

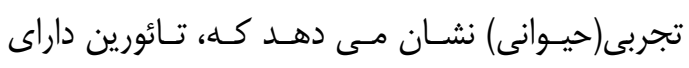

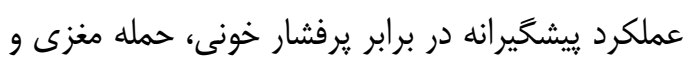

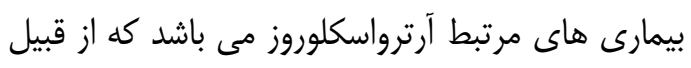
افزايش جربى هاى مضر همانند كلسترول لييـويروتئين

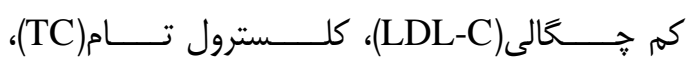

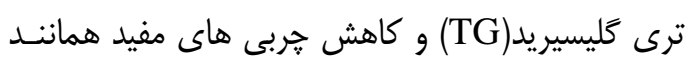

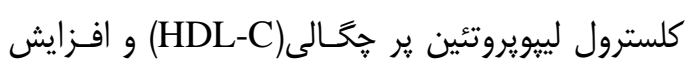

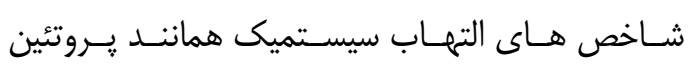




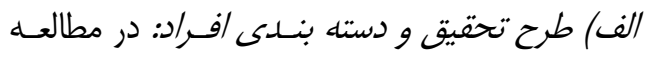

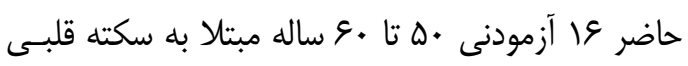

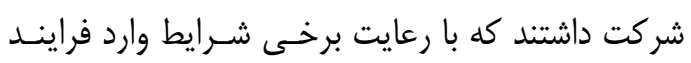

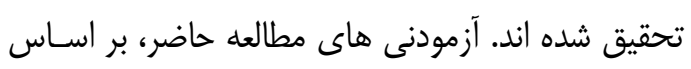

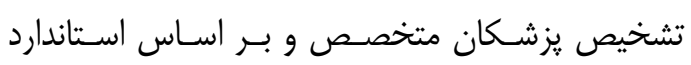

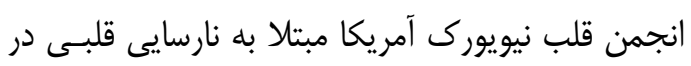

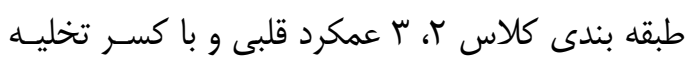

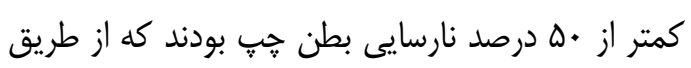

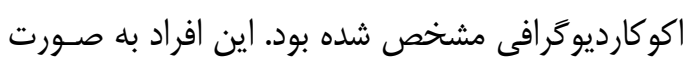
تصادفى و به ترتيـب حضـور در بيمارسـتان در يكسى از

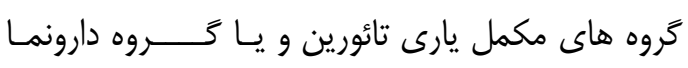

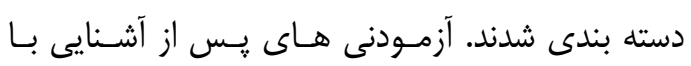

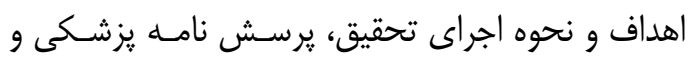

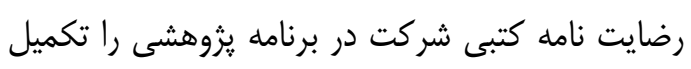

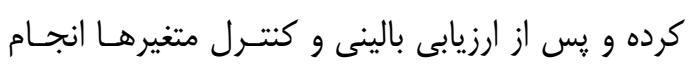

ب) شر/يط ورود /فراد به فرايند تحقيق: با توجه به عوامل مختلف اثرگذار بر نتايج تحقيق و براى كنترل

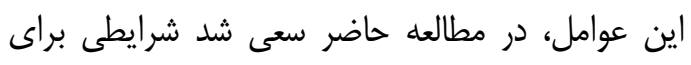

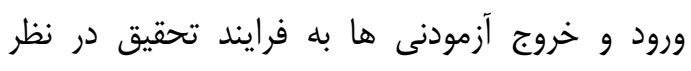

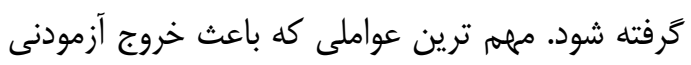
به فرايند تحقيق بود عبارتند از: افراد با نارسايى شناخته شده كليوى(افزايش نسبت ازت اوره خون به به كراتينين

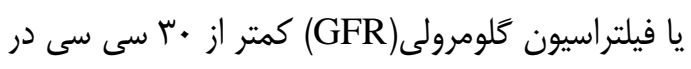

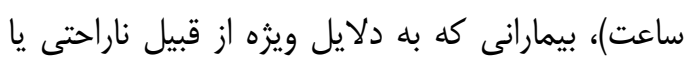

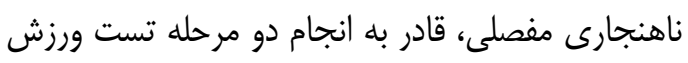

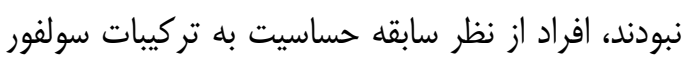

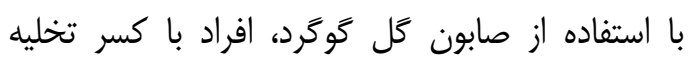

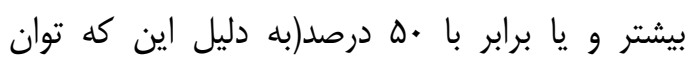

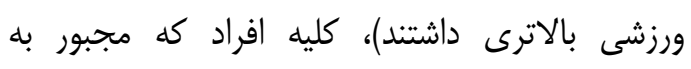

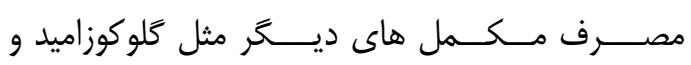
ويتامين هاى مينرال بودند، افراد مصرف كننده الكل(به ديه دليل تاثير مــصــرف الكل در عملكرد مناسب مكمل

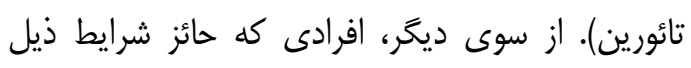

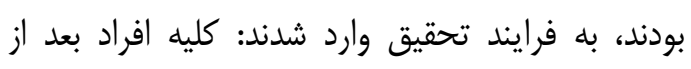
حادثه سكته قلبى در مناطق مختلف قلب، به دليل نكروز بافت قلب و نياز به انجام روش هــــاي درمــانى دئه
LDL-C بـ HDL-C بـ HC بـ HDL-C ، بـ HDL-C

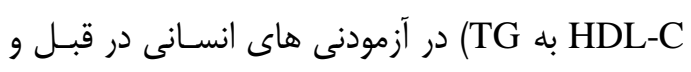

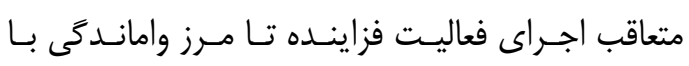

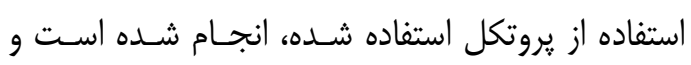

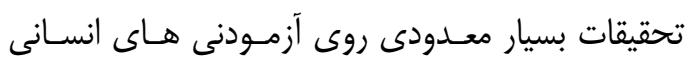

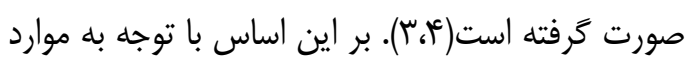
مذكور جند نكته قابل توجه مى باشد؛ اول اين كه اكثـر

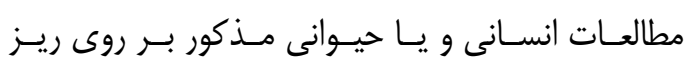

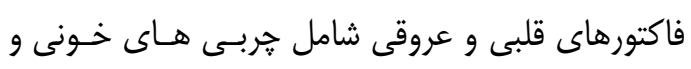

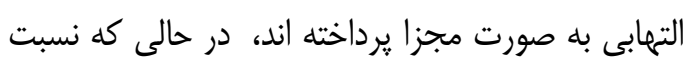

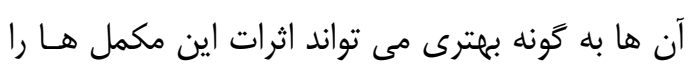

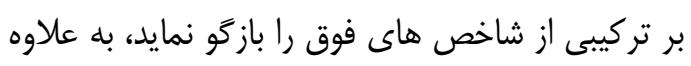

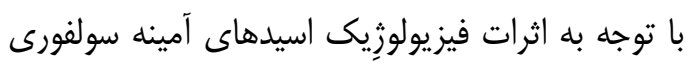

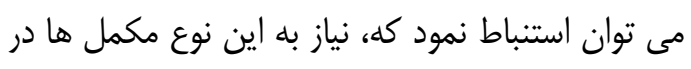

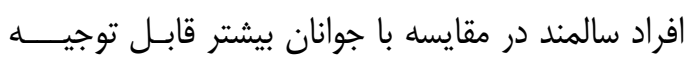
مى باشد؛ اين در حالى است كه اين موضوع بــهـ طـور جدى مورد عنايت محققان داخل و خـارج كشـور قـرار

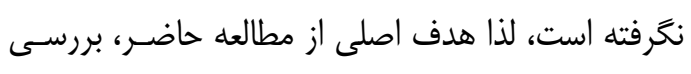

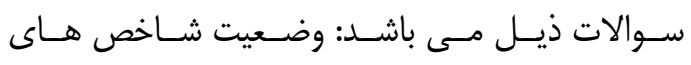

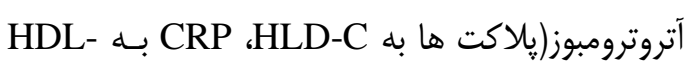

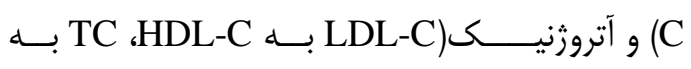

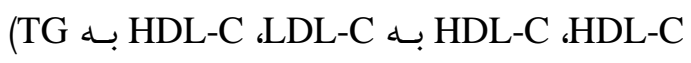

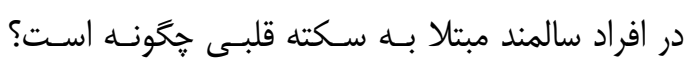
مكمل كيرى دو هفته اى تائورين خه تاثيرى بر سطوح

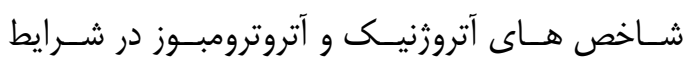

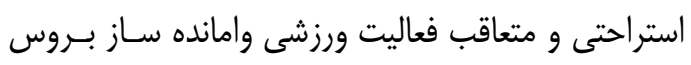
اصلاح شده دارد؟

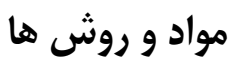
با توجه به اين كه آزمودنى هاى اين يزوهش انس انسان

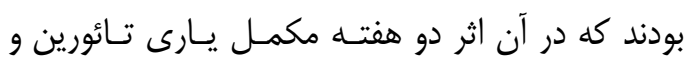

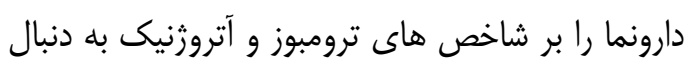

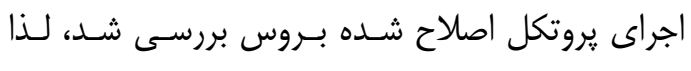

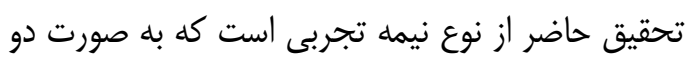

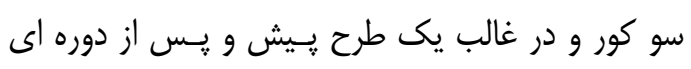

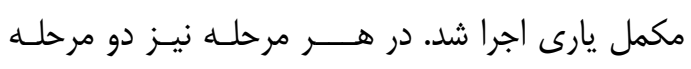

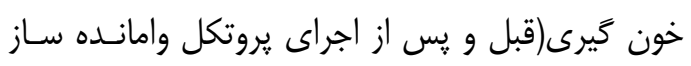
اصلاح شده بروس) انجام شد. 
Y-روش تست اصـلاح شـده بـروس نيـز شـامل 9

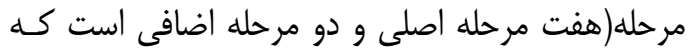

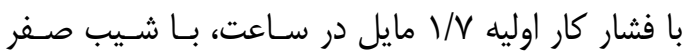
درصد شروع شــه و شـيب دسـتخاه نيـز بعـد از با و و دقيقه به ه درصد افزايش مى يابد. سيس شيب دست دستخاه هر ץ دقيقه به ميزان r درصد افزايش مى يابد. آزمـون

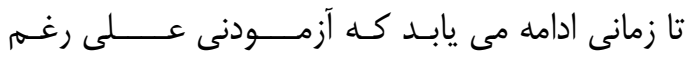

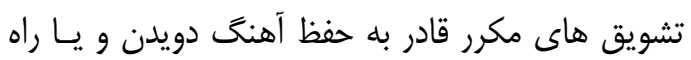

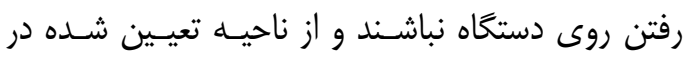

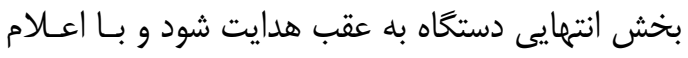
فرد مبنى بر ناتوانى در ادامه فعاليت دهار واماندگى شده شهاه

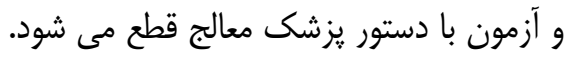

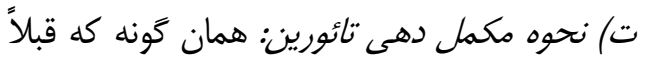

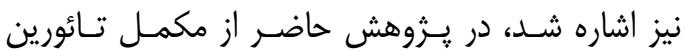
استفاده شد. اين مكمل به صورت كِيسول از انغلستـتان

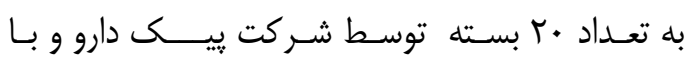

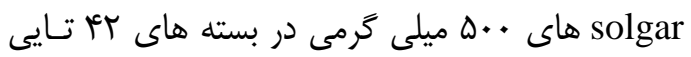

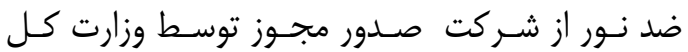
بهداشت نظارت بر دارو و مواد مخدر و اقلام خريـدارى

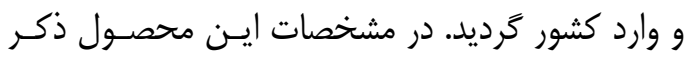
شده كه اين محصول از نظر مصرف كاملاً سالم بوده و

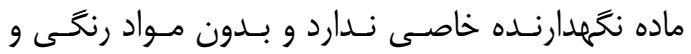
افزودنى هاى ديخــر اسـت. ايـن مكمـل شـامل شـكر، نشاسته، شير، كلوتن، نمك و اسيد آمينه سولفوريا است. كزارشى در خصوص عوارض استفاده از آن وجود ندارد،

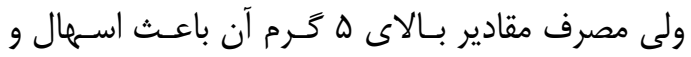

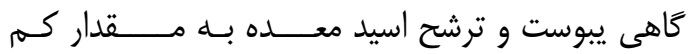

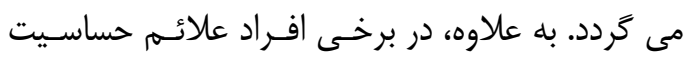

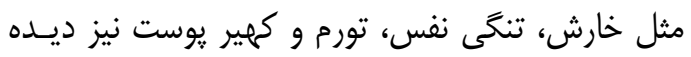

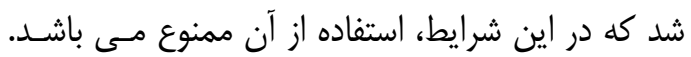

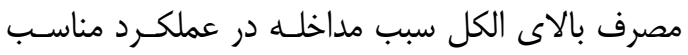

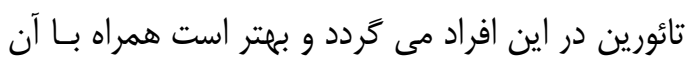

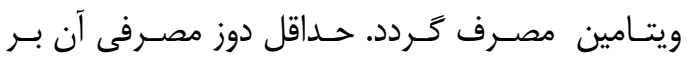

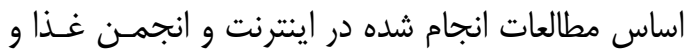

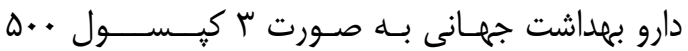

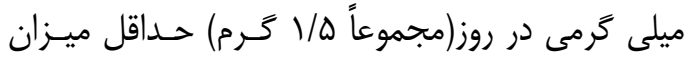

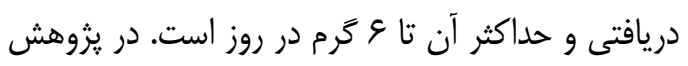

تحت بالن، جراحى قلــب باز، آنزيـــوخَـــرافى و ميل زدن(استتت دارويى و يا بدون دارو) قرار داشتند و به به باتئ

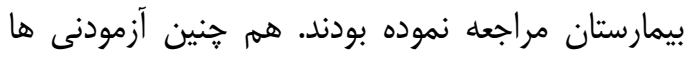
داراى سابقه يكى از فاكتورهاى ايجادكننده نارسايى نودنى

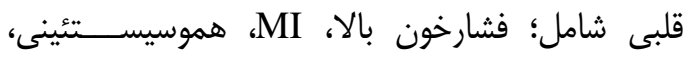

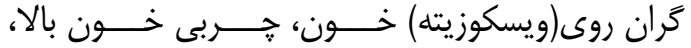
بيمارى هاى دريجه اى، كارديوميوياتى و ديابت بودندان

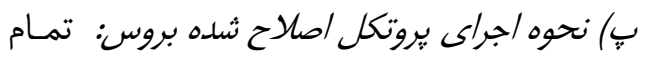

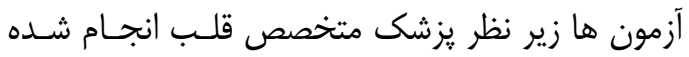

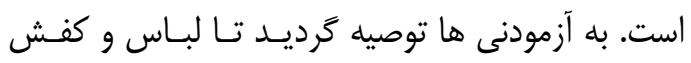

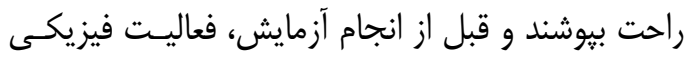

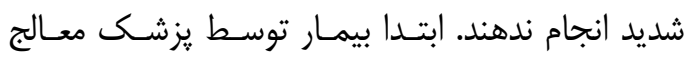

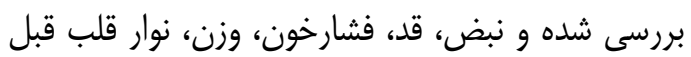

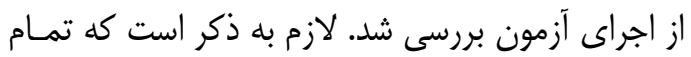

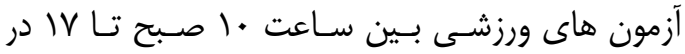

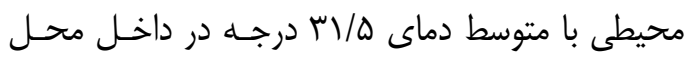

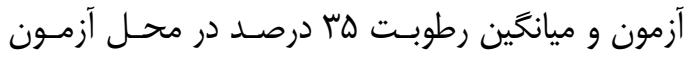

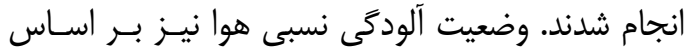

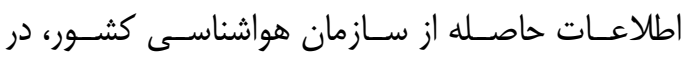
وضعيت سالم قرار داشت و سيس آزمون اصـلاح شـــــاه بروس با شرايط ذيل اجرا شد.

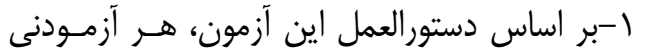

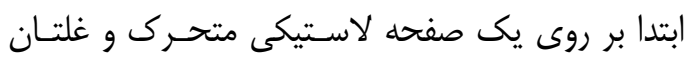

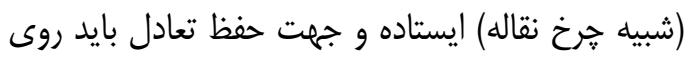

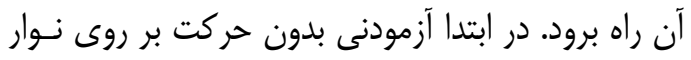
گردان ايستاده و در حالى كه فرايند الكتروكارديوگرام او او بران

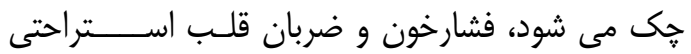

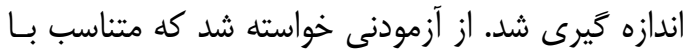

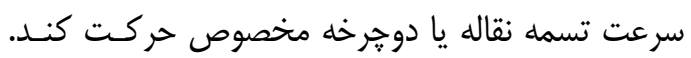

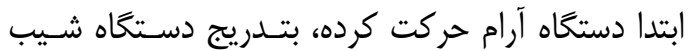
ييدا مى كند و حالتى مى شود كه فرد براى ادامـه دادن

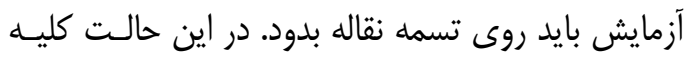
حالت هاى بيمار، نوار قلب و تغييـرات قطعـات و امـواج نوار در حالت ورزش مشخص مى گردد. بهترين نتيجهـ

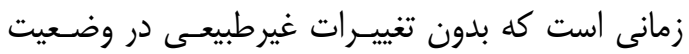

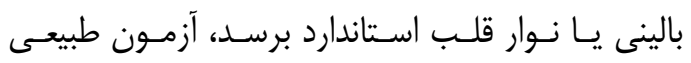

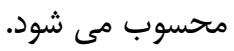


اندازه گيرى شد. غلظت تائورين پلاسـمايى بـر حسـب واحد ميلى مول در ليتر بيان گرديد.

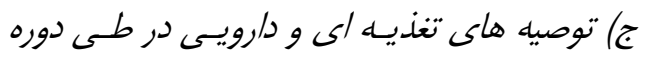

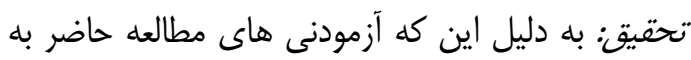
نارسايى قلبى مبتلا بودند، لذا به كليـه بيمـاران توصـيه

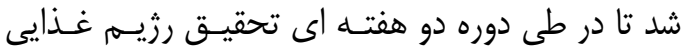
كنترل شده از نظر مصرف گوشت قرمز و امعاء و احشاء

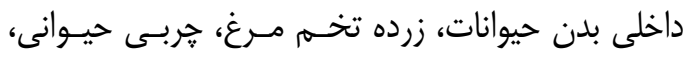

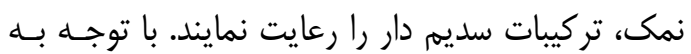
اين كه تائورين اسيد در ماهى و غـــاهاى دريـايى نيـز

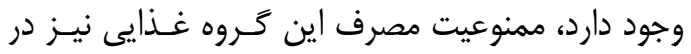

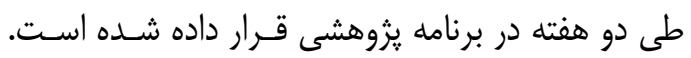

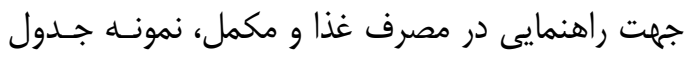

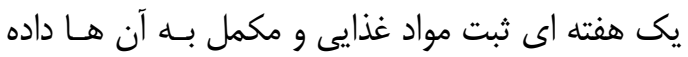

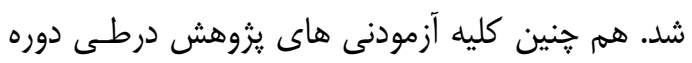

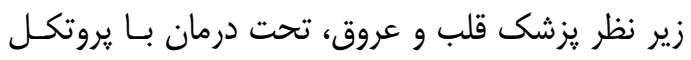

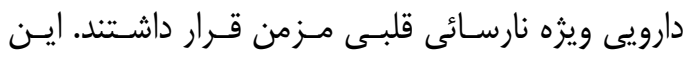

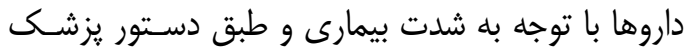

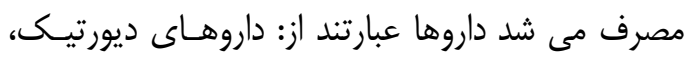

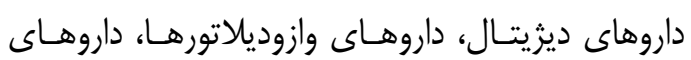

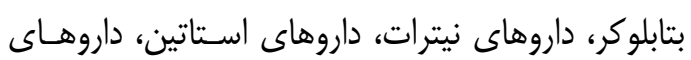
آنتى كواگولانت.

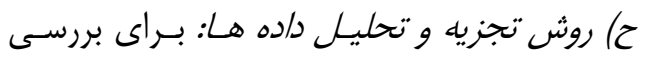

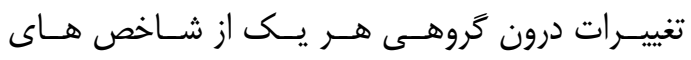

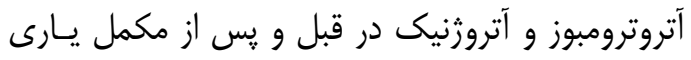

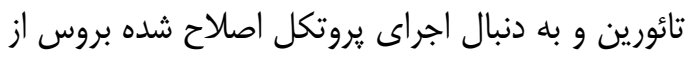

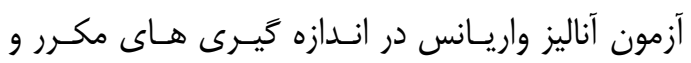

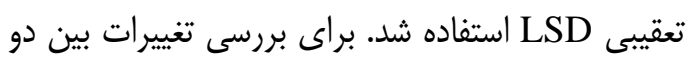

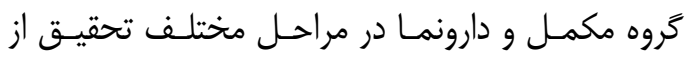

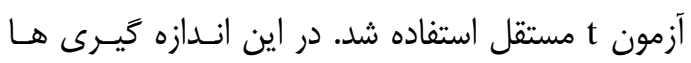

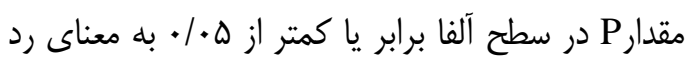
فرض صفر در نظر كرفته شد.

يافته هاى يزوهش درد درن

مشخصات آزمودنى هاى تحقيق در جدول شماره

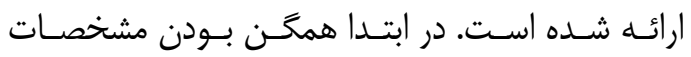

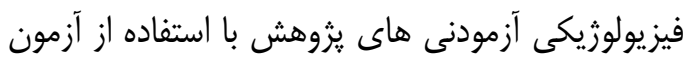
كلموگروف اسميرنوف بررسى شد. نتايج نشان داد هـيـيج

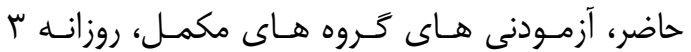

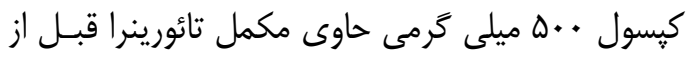

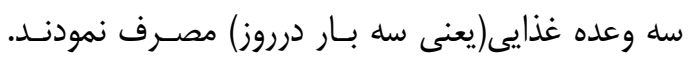

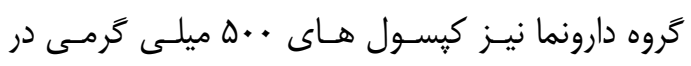

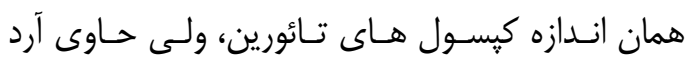
مصرف كردند كه بدون عارضه و حساسيت مى باشد.

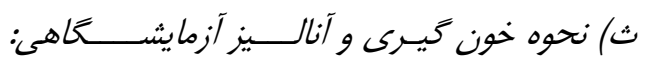
خون گيرى از آزمودنى هاى تحقيق حاضر در طى دئ دوره

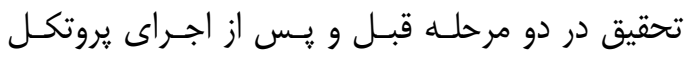

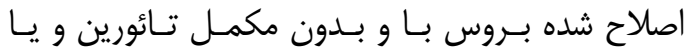

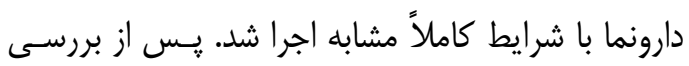
بالينى افراد اولين خون گيرى در وضعيت ناشتايى انجام

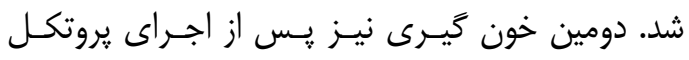

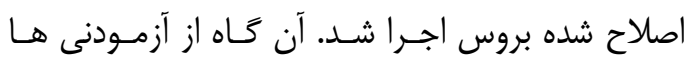

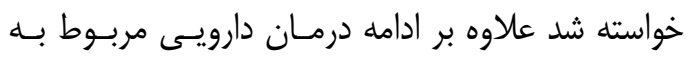

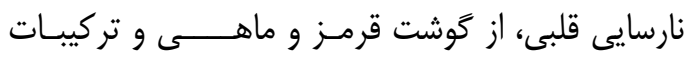

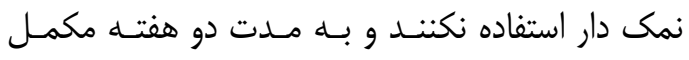

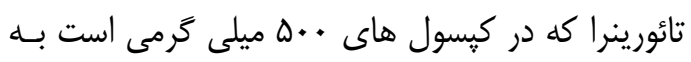

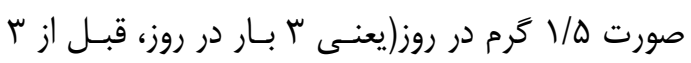

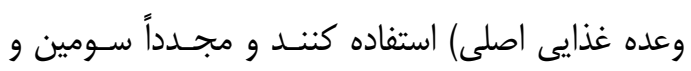

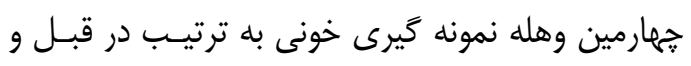

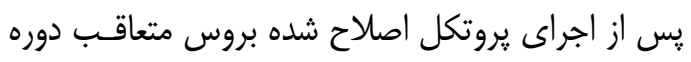

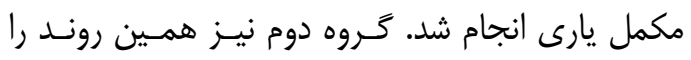

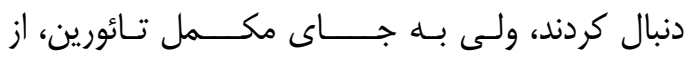

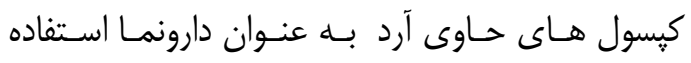

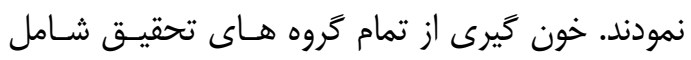

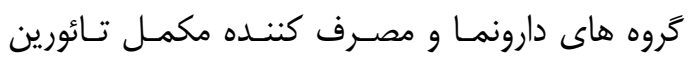

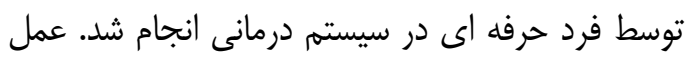

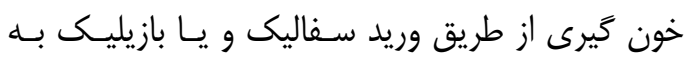

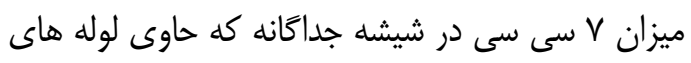

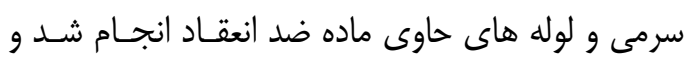

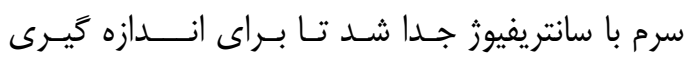

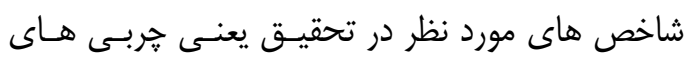

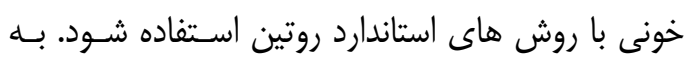

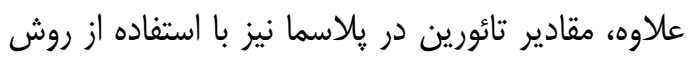

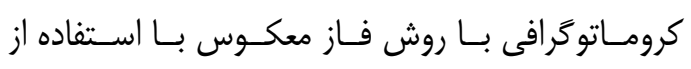
مشتقات دانسيل و دستخاه ديتكتور ساخت كشور آلمـان 
تفاوت معنى دارى بين مقادير سـن، وزن، قـد، تركيـب بلنى و درصد جربى بدن دو گروه وجود نداشت.

\begin{tabular}{|c|c|c|c|}
\hline \multicolumn{4}{|c|}{ يارى تائورين و كَروه دارونما در ابتداى تحقيق } \\
\hline مقادير معنى دارى(P) & دارونما & مكمل & كرو \\
\hline.$/ 999$ & $9 \cdot / r+N / r$ & $9 \cdot / T+\Delta / F^{6}$ & سن(سال) \\
\hline.$/ 999$ & $9 \cdot / 1 r+\Delta / r \Delta$ & $99 / \Delta+r / 1)$ & وزن (كيلو كَرم) \\
\hline ./994 & $|9 \phi+\varphi /|$ & $\mid \varphi \Delta / \varphi+\varphi / \mu$ & قدا(سانتى متر) \\
\hline.$/ 999$ & $r / \mu r+1 / 1$. & $T \varphi / T+1 / \cdot \Delta$ & BMI (كيلوكرم بر مترمربع) BMI \\
\hline . / N९D & $r q / \Delta f+\varepsilon / r q$ & $T N / T)+V / T \Delta$ & VMax (ميلى ليتر/كيلوكر م/دقيقه) \\
\hline
\end{tabular}

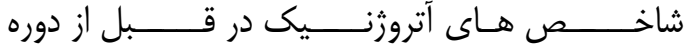

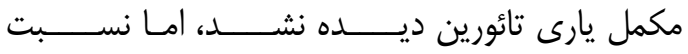

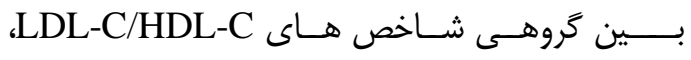
TG/HDL-C g TC/HDL-C

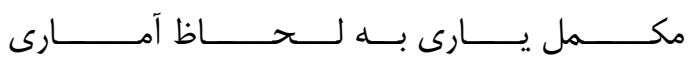

معسـنادار بــــــوده است.
شاخص هاى آتروزنيك: تغييرات مقادير نسبت هـر

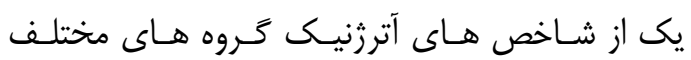

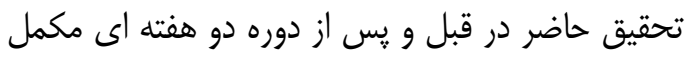

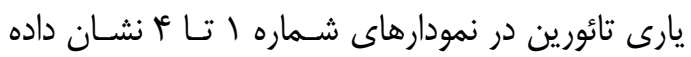

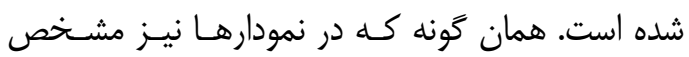

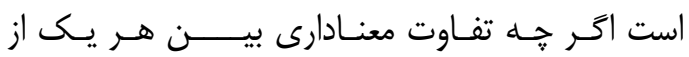

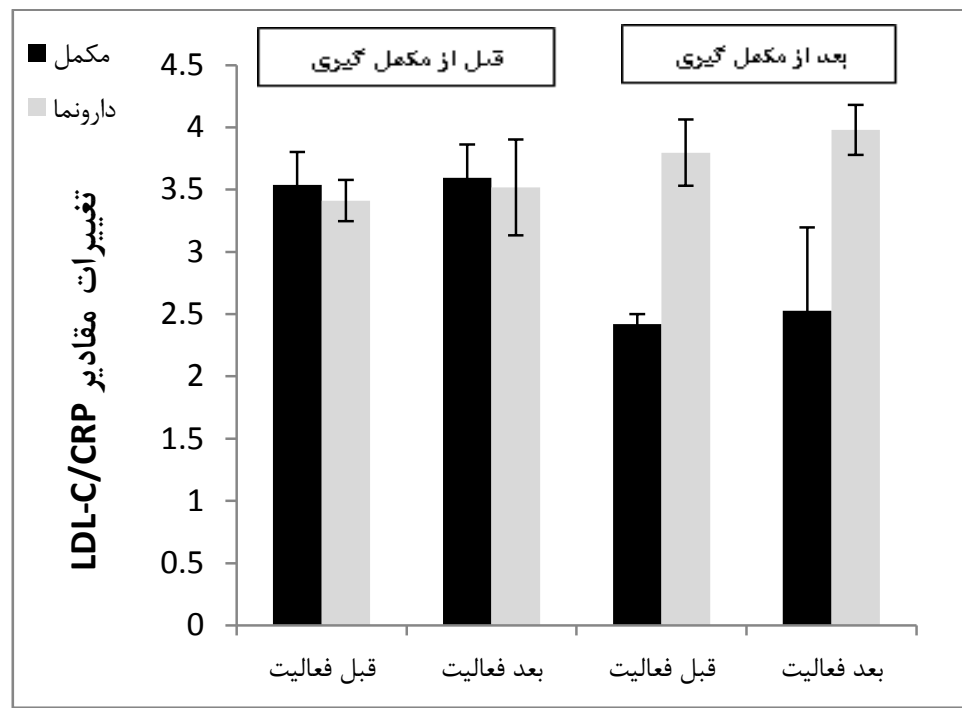

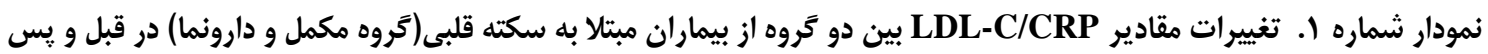

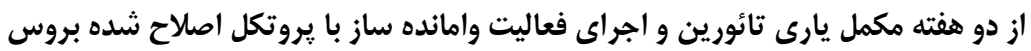




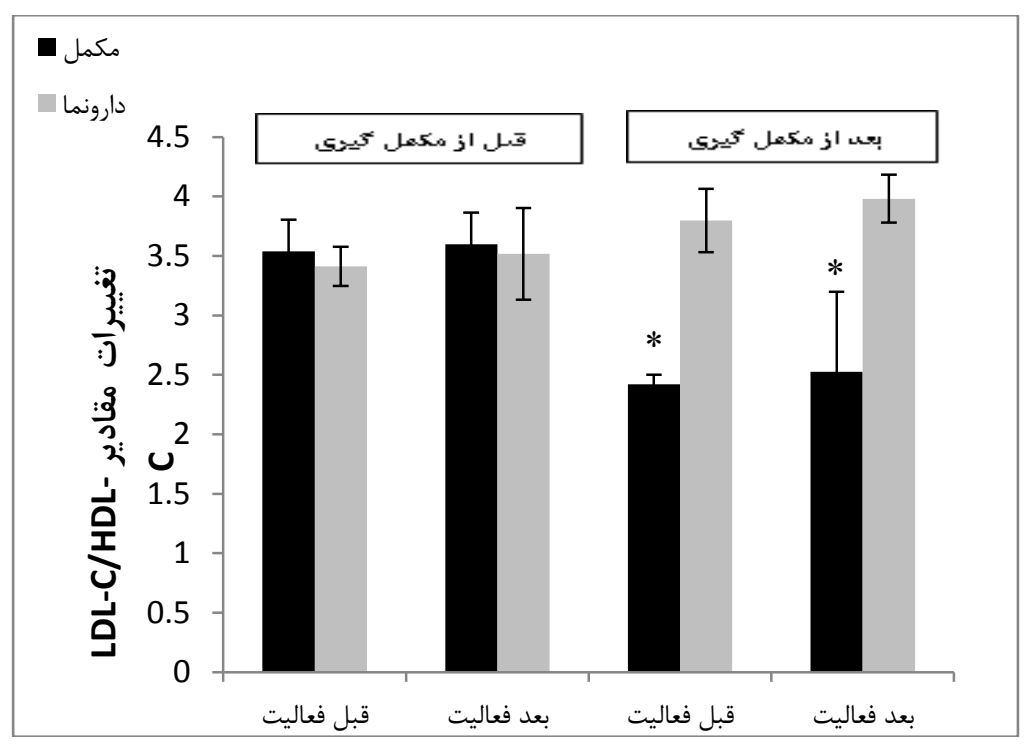

نمودار شماره r. تغييرات مقادير LDL-C/HDL-C بين دو كروه از بيماران مبتلا به سكته قلبى(كروه مكمل و دارونما) در قبل و

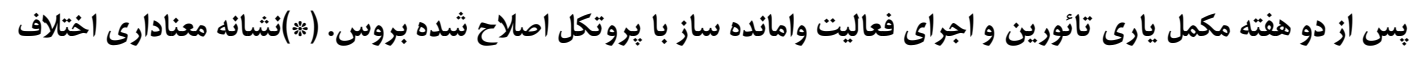

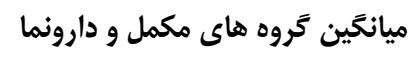

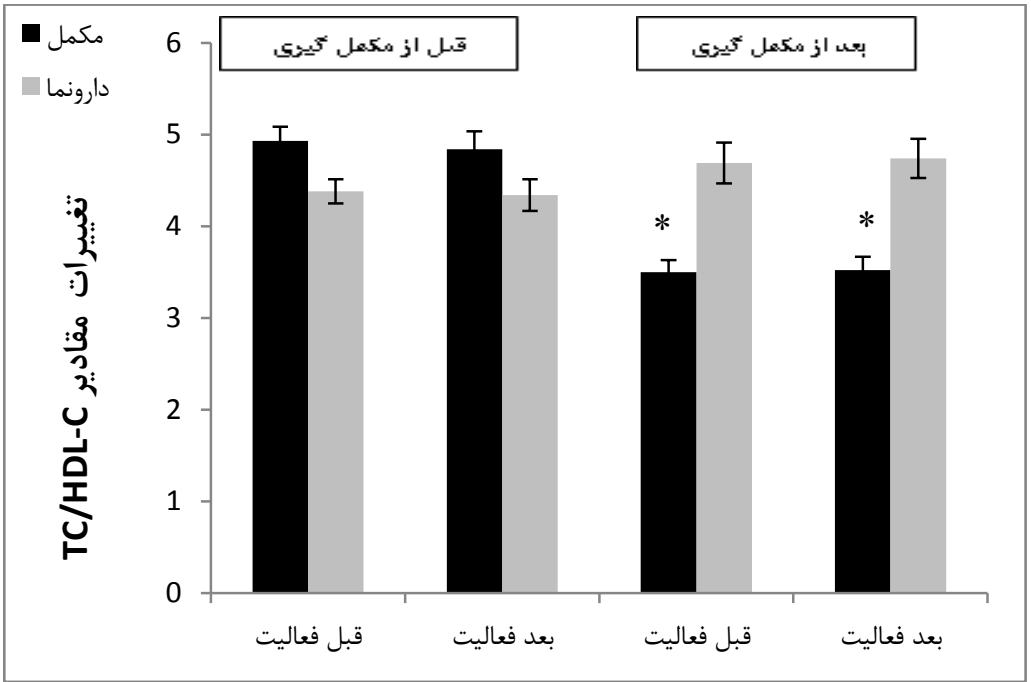

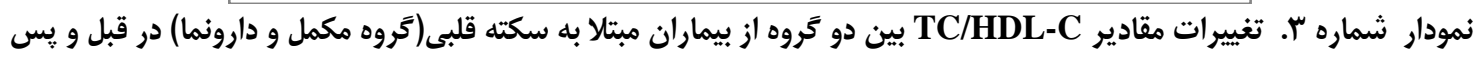

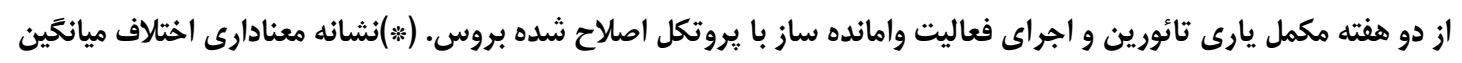

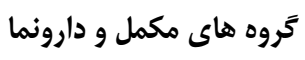




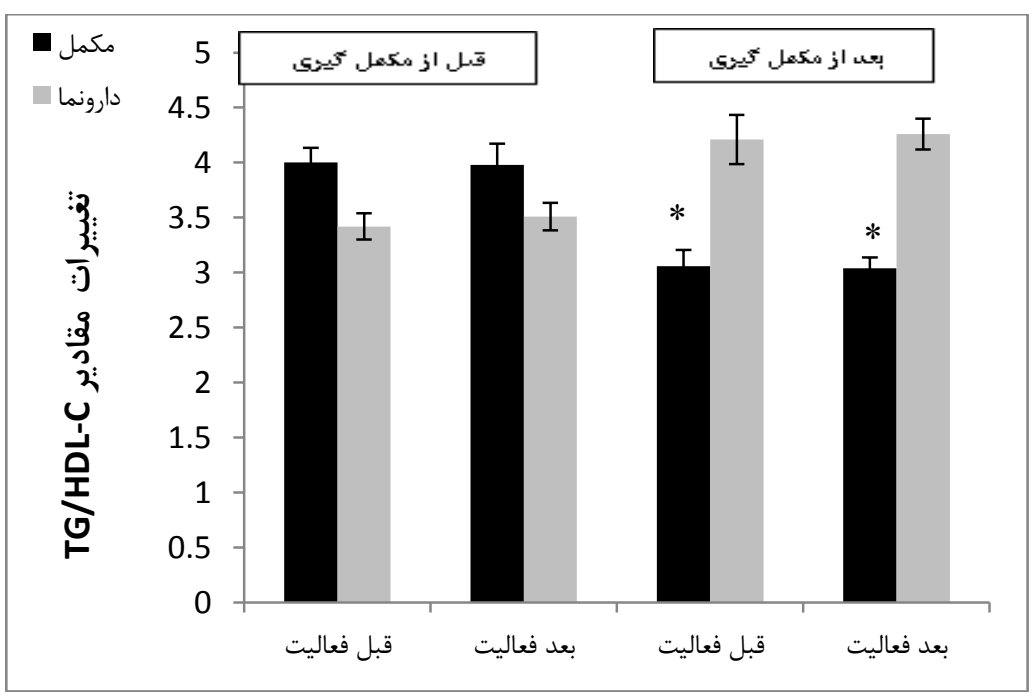

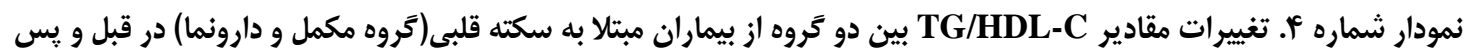

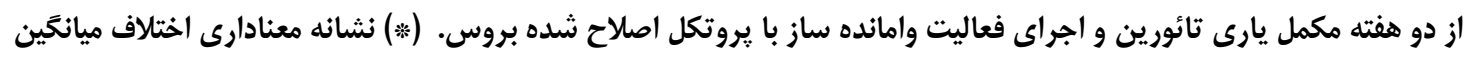
تروه هاى مكمل و دارونما

مكمل يارى تـائورين بـين دو خـروه مكمـل و دارونمـا

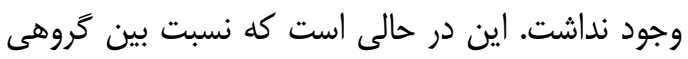

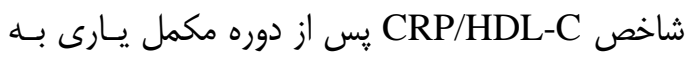

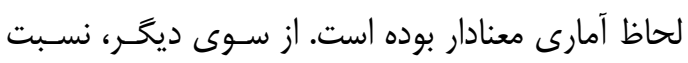

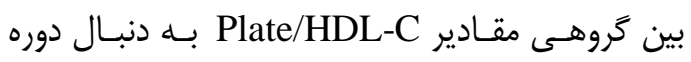
مكمل يارى در قبل از اجراى فعاليـت روى نـواركردان

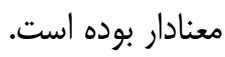

شاخص هاى آتروترومبوز: نمودارهاى شـماره هـ و

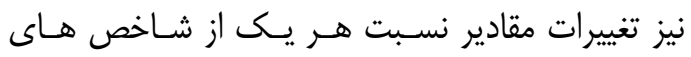

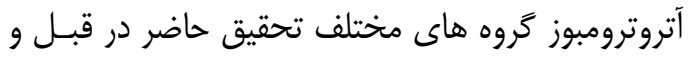
هي از دوره دو هفته اى مكمل يارى تـائورين نشـانــان

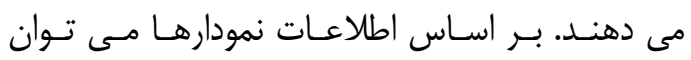
ملاحظه نمود كه تفاوت آمارى معنـادارى بسين مقـادير

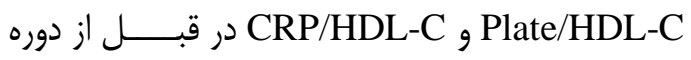

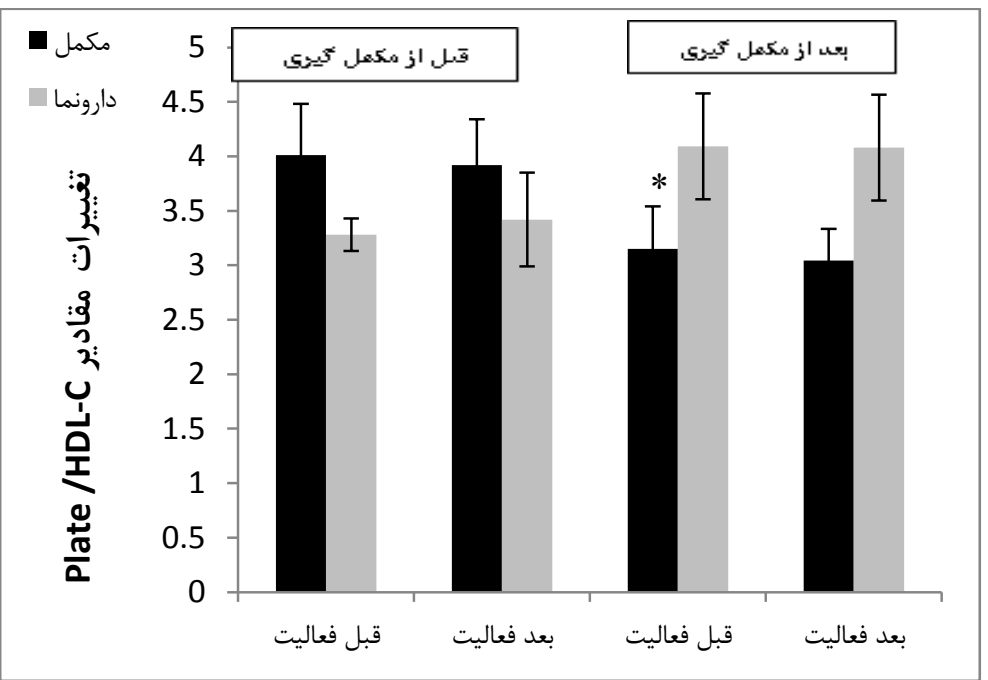

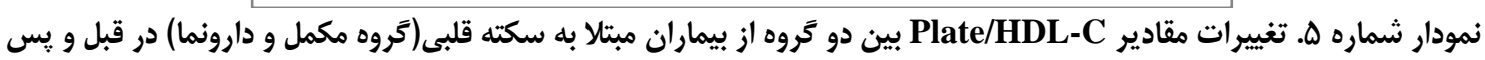

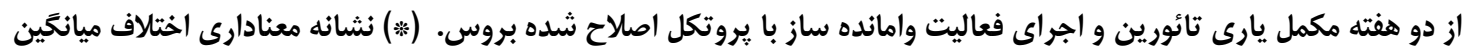

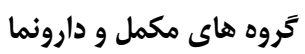




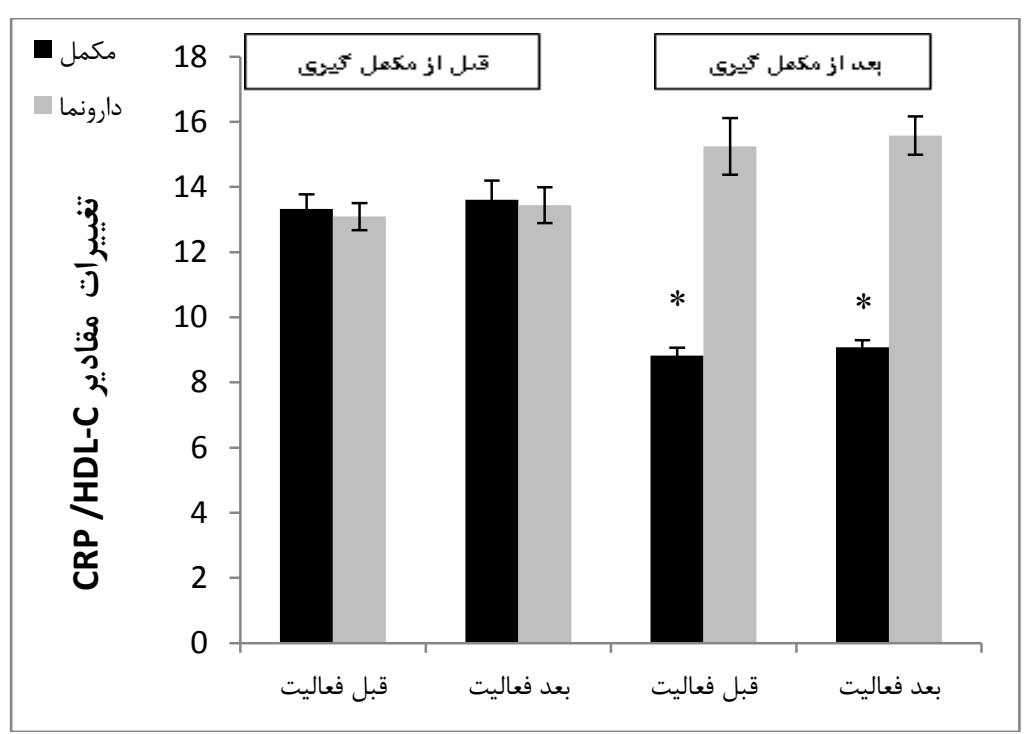

نمودار شماره צ. تغييرات مقادير CRP/HDL-C بين دو تروه از بيماران مبتلا به سكته قلبى(كروه مكمل و دارونما) در قبل و ويس

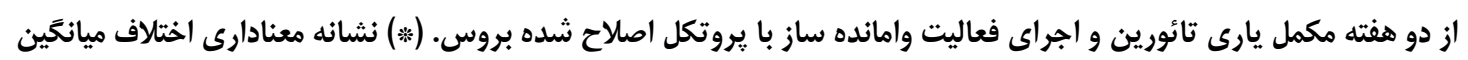

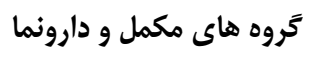

باعث تخفيف در سطوح خربى هـاى خـونى و عملكـرد

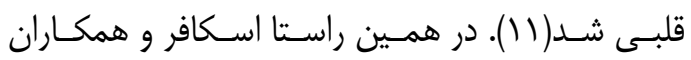

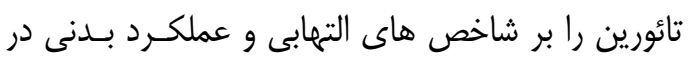

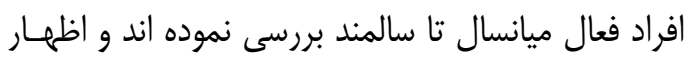

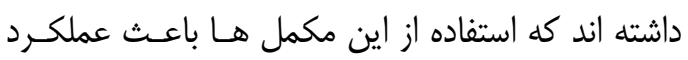

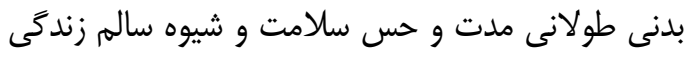

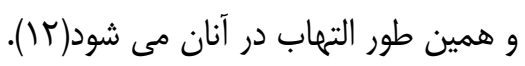

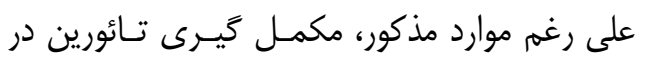

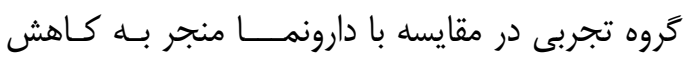

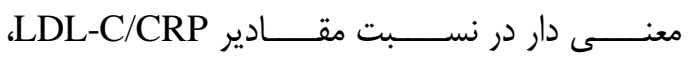
TG/HDL-C و TC/HDL-C

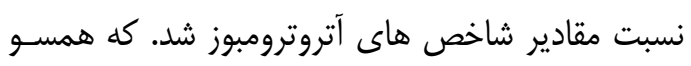

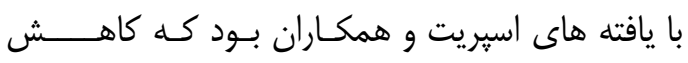

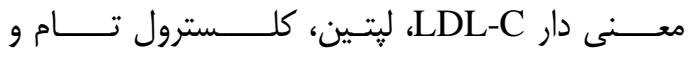
ترى كليسيريد به دنبال مصرف مكمل تائورين را نسبت

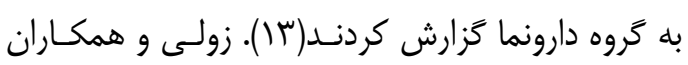

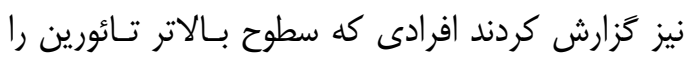

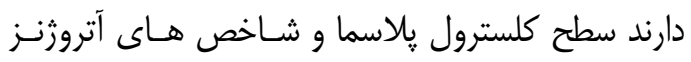

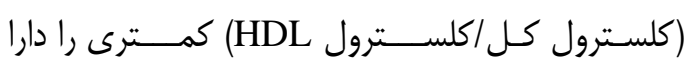

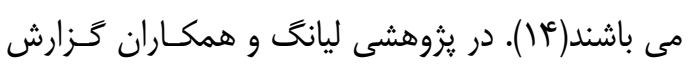

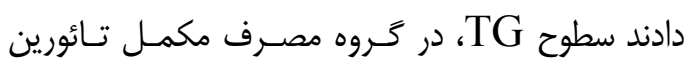
كاهش معنى دار يافت(ه). در يزوهشى ديخر ساداكو و

\section{بحث و نتيجه كَيرى}

مطالعه حاضر در زمره نخستين ميرى مطالعاتى است كـهـ

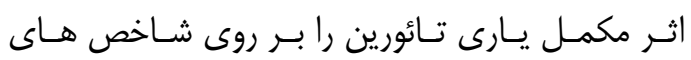

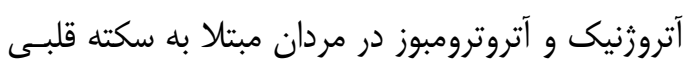
بررسى نموده است. يثزوهش حاضـر نشـان داد مكمـل

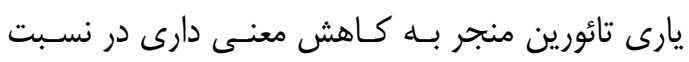

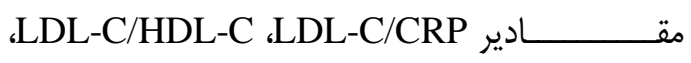
Plate/HDL- Tو و نسبت TG/HDL-C ،TC/HDL-C

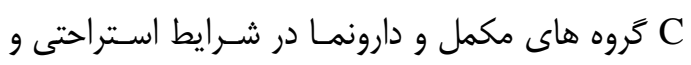

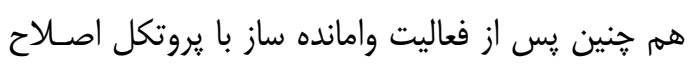

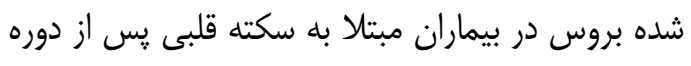

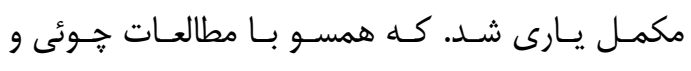

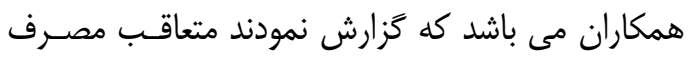
مكمل تائورين مقادير كلسترول تام و ترى كليسيسيريدها

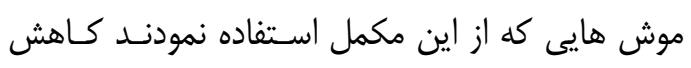

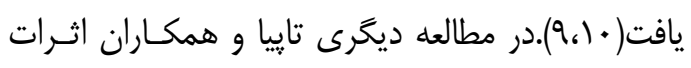

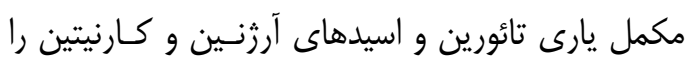

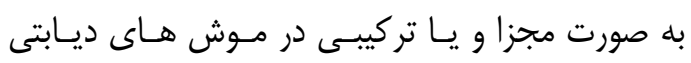

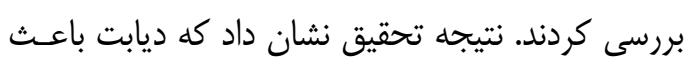

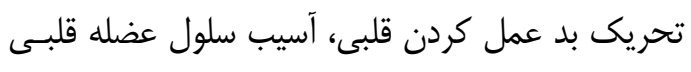

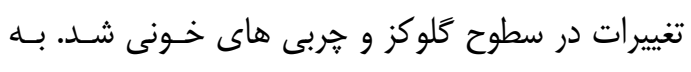
علاوه، درمان موش هاى ديابتى با اسـتفاده از تـائورين 
تعويق مى اندازد(·r). مطالعات فـــــاگير نيـز نشــــان

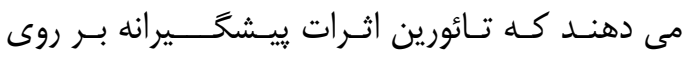

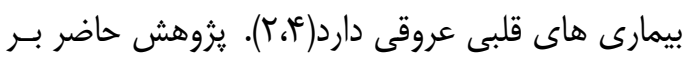

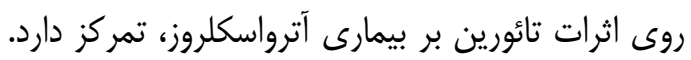

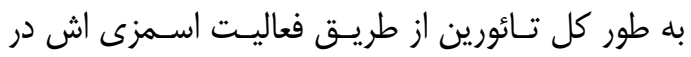
كليه، تنظيم ترشـح عامـل ســيمى دهليـزى و تنظـيم

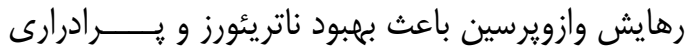

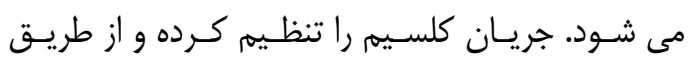

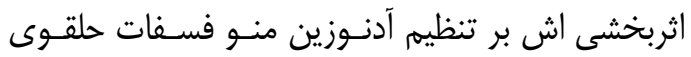

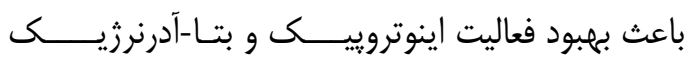

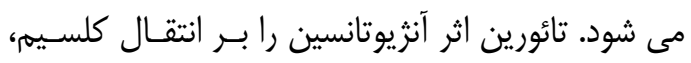

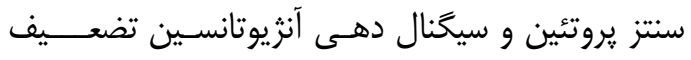

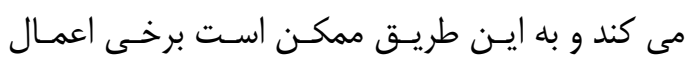

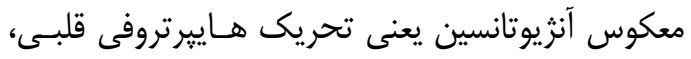

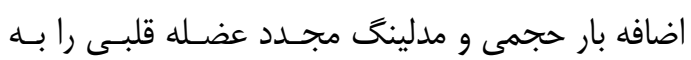

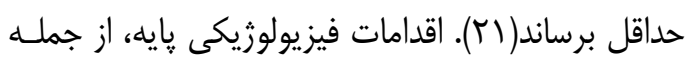

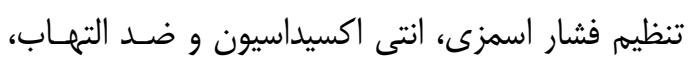

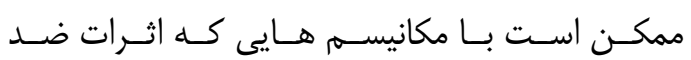

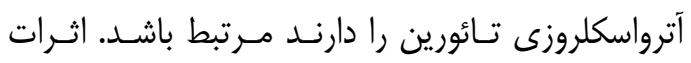

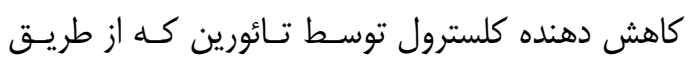
بهبود سوخت و ساز كلسترول كبدى به دست مسى آيـد

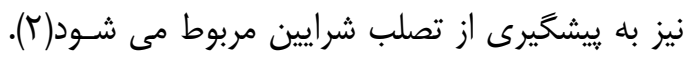

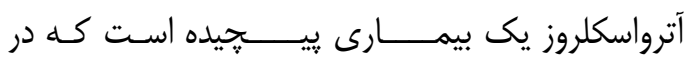

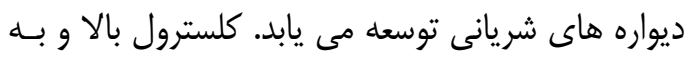

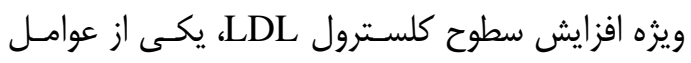

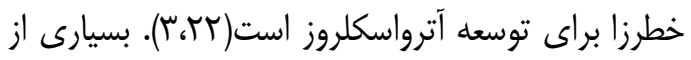

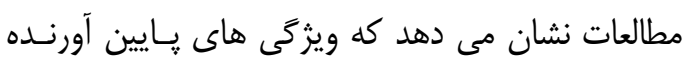

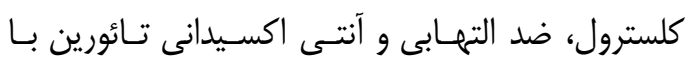

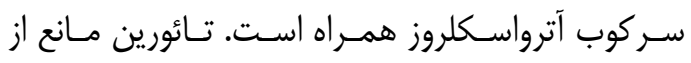
افزايش سطح LDL و كلسترول VLDL ناشى از رزيم

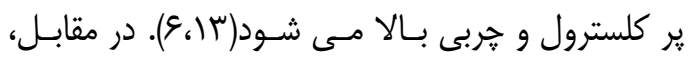

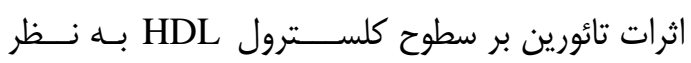

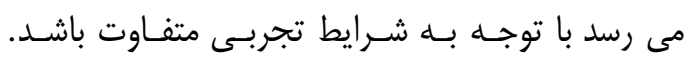

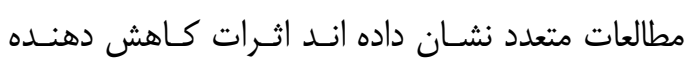

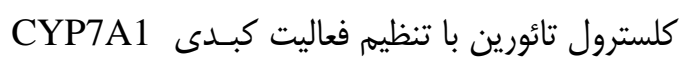
3-3 و هيدروكسى س متيـل كـوآنزيم) A(HMG-COA

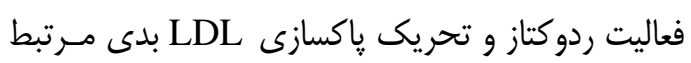
است. علاوه بر اين، تائورين افزايش توليد اجسام كتونى
همكاران(ז) كزارش كردنـــــــ إز مصـرف تـائورين،

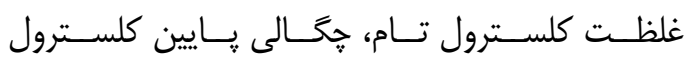
لييويرتئين(LDL-C)، كلسترول آزاد و تـرى كلسـيريد

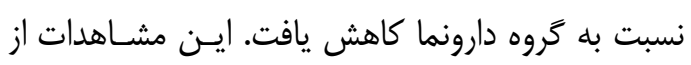

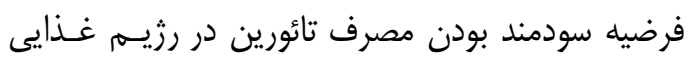

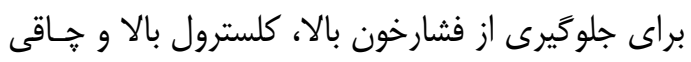

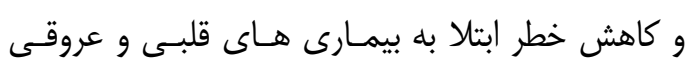

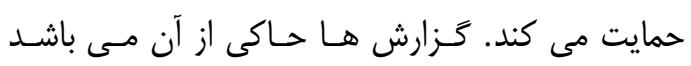

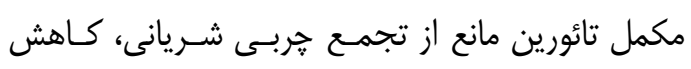

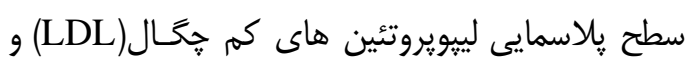

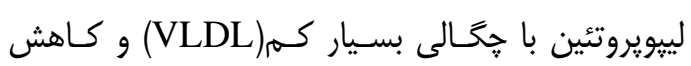

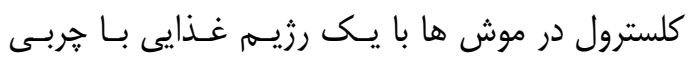

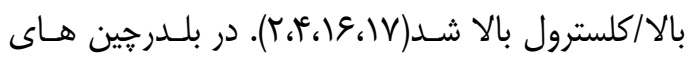
زازينى با خربى خون بالا و مستعد به تصلب شرايين، كه

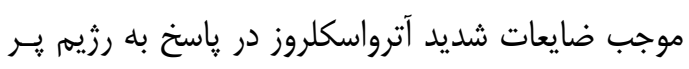

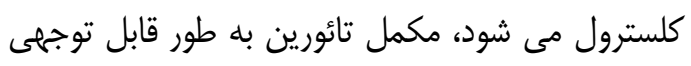

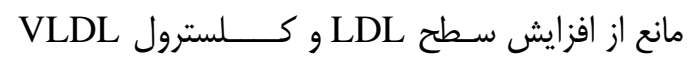

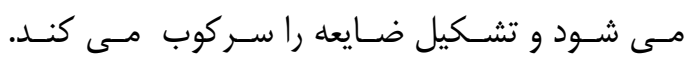

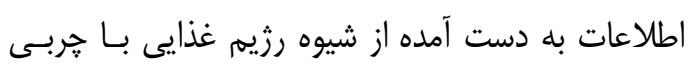

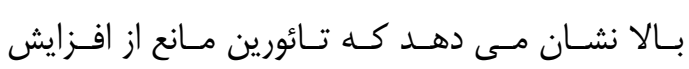

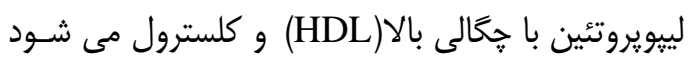

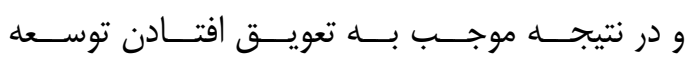

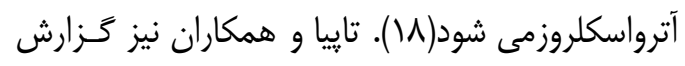

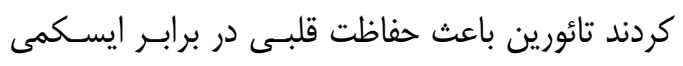

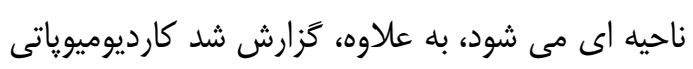

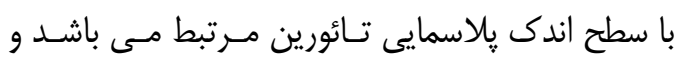

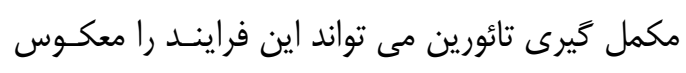

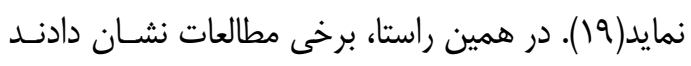

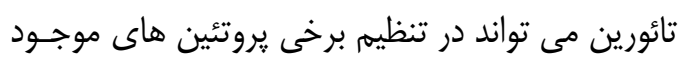

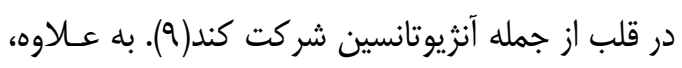
برخى محققان گزارش دادند افزايش فعاليت سـايتوكين

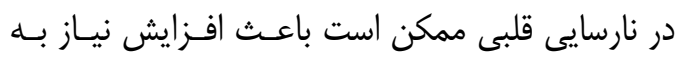

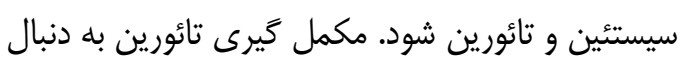

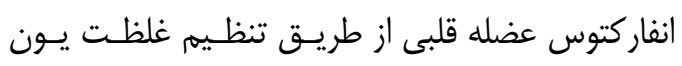

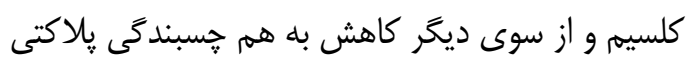

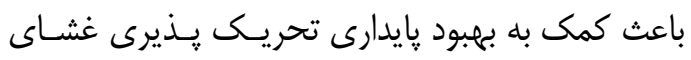

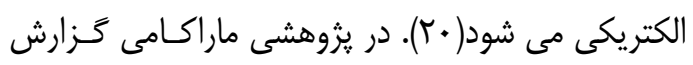

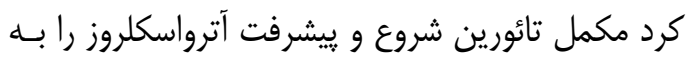


از طريق مهار آيويتوز و جسبندگى مولكول ها محافظت

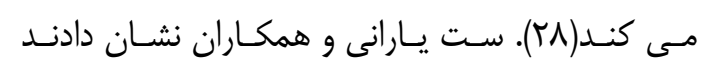

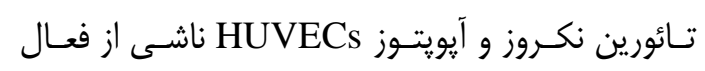

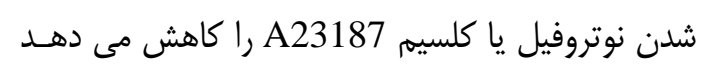

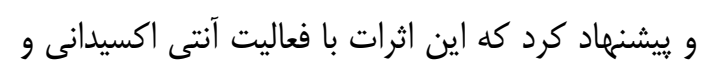

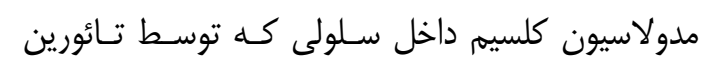

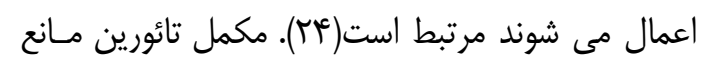

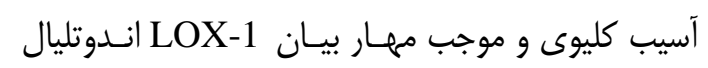

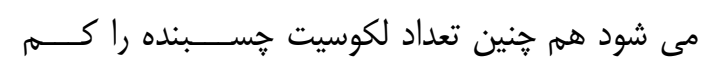

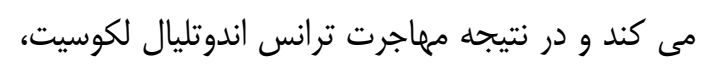

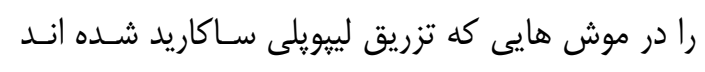

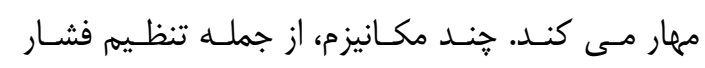

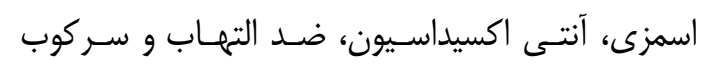
LOX-1 سلول هاى اندوتليال مرتبط باشند(بس-وج).

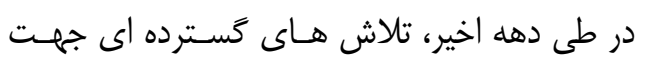

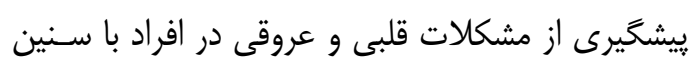

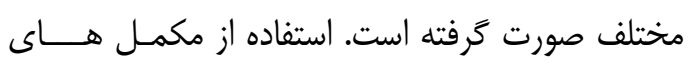

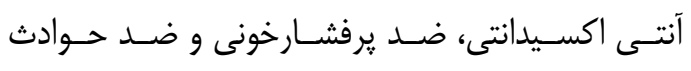

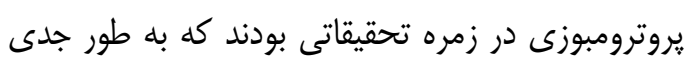

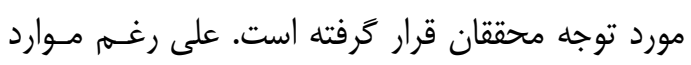

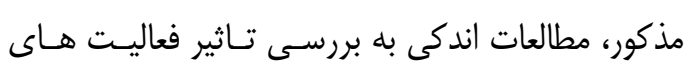

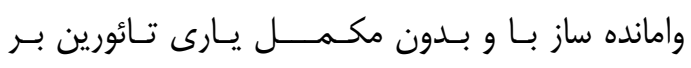

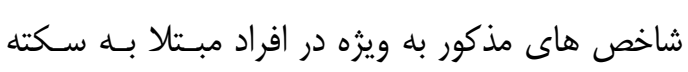

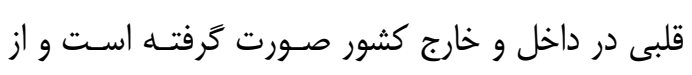

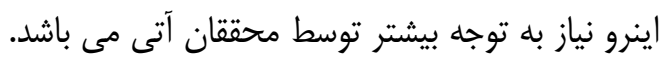

\section{References}

1.Rana J, Liu JY, Howard HM, Matthew S, Alan S, Jaffe $M$, et all. Metabolic dyslipidemia and risk of coronary heart disease in adults with diabetes and low ldlcholesterol. J Am Coll Cardiol 2015;65:10. DOI:10.1016/S0735-1097(15)61341-9.

2.Fen $\mathrm{Wu}$, Koenig KL, Zeleniuchjacquotte A, Jonas S, Afanasyeva Y. Serum taurine and stroke risk in women a prospective nested case-control study. J Pone 2016; 11:23-7. DOI:10.1371.

3.Murakami S, Sakurai T, Tomoike H, Sakono M, Nasu T, Fukuda N. Prevention of hypercholesterolemia and atherosclerosis in the hyperlipidemia and atherosclerosis-
و اكسيداسيون اسيد جرب را افزايش مى دهد. تـائورين

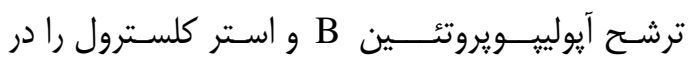

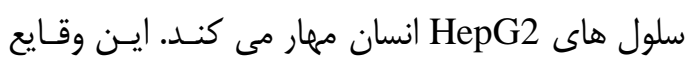

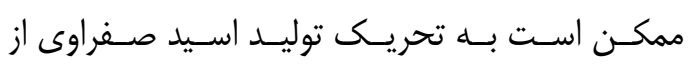

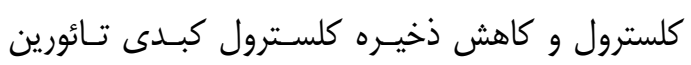

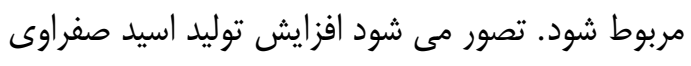
مسئول اعمال كاهش دهنده كلسترول توسـط تـائورين

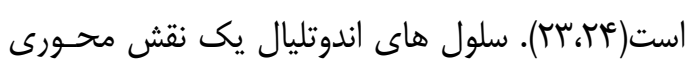

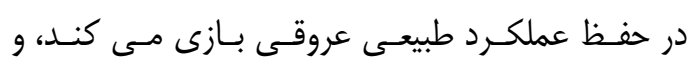

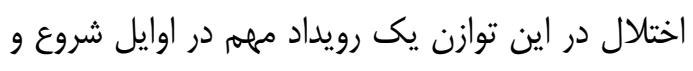
توسعه بيمارى تصلب شرايين است. اندوتليوم عروقى به ديه

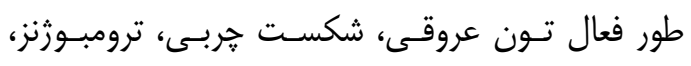

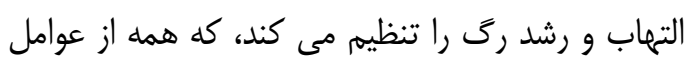

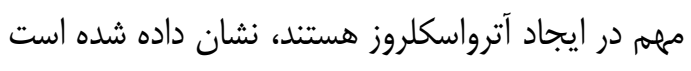

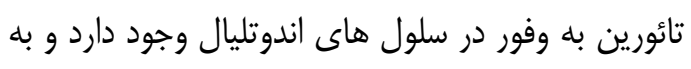

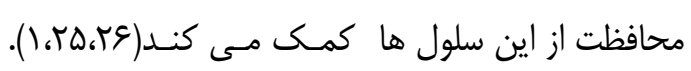
تائورين نقش مهمى در تنظيم اسمولاريته در انسدوتليال

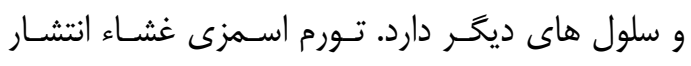

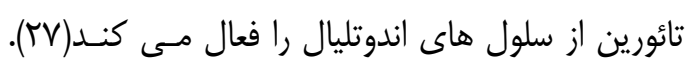

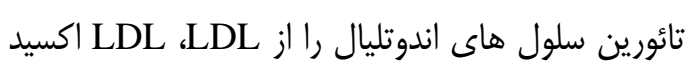

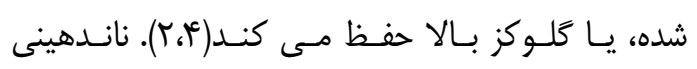

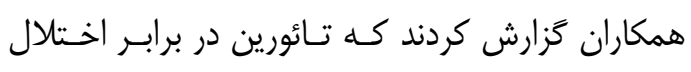

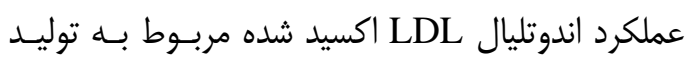

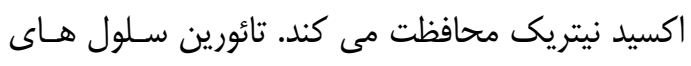

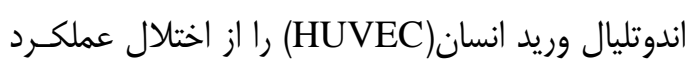

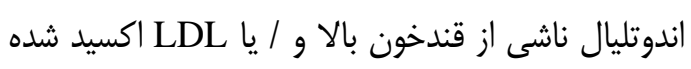

prone Japanese LAP quail by taurine supplementation. Amino Acids 2010 ;38:271-8. DOI: 10.1007/s00726-009-02476.

4.Sadako M, Chizuko M, Hiroe A, Sachie H, Tamami A, Hiroshi Y, et all. Effects of taurine intake on serum lipids in young women. Func Foods Health Dis 2015; 5 :155-64.

5.Dasilva LA, Tromm CB, Bom KF, Mariano I, Pozzi B, Rosa GL, et all. Effects of taurine supplementation following eccentric exercise in young adults. Appl Physiol Nutr Metab 2014;39:101-4. DOI: 10.1139/apnm-2012-0229 
6. Kuwahara M, Kawaguchi T, Ito $\mathrm{K}$, Tsubone $H$. Effects of taurine on cardiovascular and autonomic nervous functions in cold exposed Rats. Adv Exp Med Biol 2009;643:533-40.DOI: 10.1007/978-0-387-75681-3_55.

7. Faggiano A, Melis R, Alfieri MC, Martino M, Filippella F. Sulfur amino acids in cushings disease insight in homocysteine and taurine levels in patients with active and cured disease. J Clin Endocrinol Metab 2005;90:616-22. DOI:10.1210/jc.20050656

8. Nandhini AT, Balakrishnan SD, Anuradha CV. Taurine improves lipid profile in rats fed a high fructose diet. Nutri Res 2002; 22:343-54. DOI:10.1016/S02715317(01)00391-8

9.Choi MJ, Chang KJ. The effects of dietary taurine supplementation on plasma and liver lipid in ovariectomized Rats. Epidemiol Stud J Biomed Sci2009;17:38995.DOI: 10.1007/978-0-387-75681-3_40.

10. Choi, MJ. Effects of dietary taurine supplementation on plasma and liver lipids in OVX rats fed calcium deficient diet. Nutr Res Pract 2008;2: 6-13.

11.Tappia PS, Thliveris J, Xu YJ, Aroutiounova N, Dhalla NS. Effects of amino acid supplementation on myocardial cell damage and cardiac function in diabetes. Exp Clin Cardiol 2011; 16:17-22. 12. Schaffer SW, Lombardini GB, Azuma J. Interaction between the actions of taurines and angiotensin II. Amino Acids 2009; 18:305-18. DOI: 10.1007/PL00010320.

13. Spriet LL, Whitfield J. Taurine and skeletal muscle function. Curr Opin Clin Nutr Metab Care 2015; 18:96-101.DOI: 10.1097/MCO.0000000000000135.

14.Zulli A, Lau E, Bagus PP, Wijaya X, Jin K, Sutarga S. High dietary taurine reduces apoptosis and atherosclerosis in the left main coronary artery; association with reduced CCAAT enhancer binding protein homologous protein and total plasma homocysteine but not lipidemia. Hypertension2009; 53:1017- 22. DOI: 10.1161/Hypertensionaha.109.129924.

15.Liang H, Hung Y, Lee Y, Ting Y, Chih HY. Effect of taurine in chronic alcoholic patients. Food Func2014;5:1529-35. DOI: 10.1039/c3fo60597c.
16.Oktawia P, Wojcik, Karen L, Koenig A, Max C. The potential protective effects of taurine on coronary heart disease. NIH Publ Acc2010;208:19. DOI:10.1016. DOI: 10.1016/j.atherosclerosis.

17.Anthony Z, Eza L, Bagus PP, Xin J, Komang S, Grace D, et all. high dietary taurine reduces apoptosis and atherosclerosis in the left main coronary artery association with reduced CCAAT enhancer binding protein homologous protein and total plasma homocysteine but not lipidemia. Hypertension2010;53:101722. DOI: 10.1161/Hypertensionaha.

18. Hansen SH. The role of taurine in diabetes and the development of diabetic complications. Diabetes Metab Res Rev 2001; 17:330-346. DOI: 10.1002/dmrr.229. 19.Tappia PS, Xu YJ, RodriguezLeyva D, Aroutiounova N, Dhalla NS. Cardioprotective effects of cysteine alone or in combination with taurine in diabetes. Physiol Res2013; 16; 62:171-8.

20. Murakami SH. Taurine and atherosclerosis. Amino Acids 2014; 46:7380. DOI: 10.1007/s00726-012-1432-6.

21. Kammerer M, Jaramillo JA, Garcia A, Calderon JC, Valbuena LH. Effects of energy drink major bioactive compounds on the performance of young adults in fitness and cognitive tests a randomized controlled trial. J Int Soc Sports Nutr 2014; 7, 11:44. DOI: 10.1186/s12970-014-0044-9.

22. Sharifi M, Rakhit RD, Humphries SE, Devaki Nair. Cardiovascular risk stratification in familial hypercholesterolaemia. Heart Online First2016; 0:1-6. DOI:10.1136. doi.org/10.1136/heartjnl-2015-308845.

23. Sanya R, Lerdweeraphon P, Malila D, Jirakulsomchok JM. Perinatal taurine alters arterial pressure control and renal function in adult offspring. Adv Exp Med Bio2009; 643:145-56. DOI: 10.1007/978-0-38775681-3_15.

24.Setyarani M, Zinellu A, Carru C, Zulli A. High dietary taurine inhibits myocardial apoptosis during an atherogenic diet association with increased myocardial HSP70 and HSF-1 but not caspase 3. Eur J Nutr2014; 53:929-37. DOI: 10.1007/s00394-013-0596-5.

25.Yamori Y, Taguchi T, Hamada A, Kunimasa K, Mori H, Mori M. Taurine in health and diseases: consistent evidence 
from experimental and epidemiological studies. J Biomed Sci 2010; 24:17. DOI: 10.1186/1423-0127-17-S1-S6.

26. Welty FK. How do elevated triglycerides and low HDL cholesterol affect inflammation and atherothrombosis? Curr Cardiol Rep 2013; 15:400. DOI: 10.1007/s11886-013-0400-4.

27.Tsuboyamakasaoka N, Shozawa C, Sano Y, Kamei S, Kasaoka Y, Hosokawa A, et all. Taurine 2-aminoethanesulfonic acid deficiency creates a vicious circle promoting. Endocrinology 2006;147:327684. DOI:10.1210/en.2005-1007

28. Nandhini SD, Balakrishnan SD, Anuradha CV. Taurine improves lipid profile in Rats fed a high fructose diet.
Nutri Res 2009; 22:343-354. DOI.org/10.1016/S0271-5317(01)00391-8. 29. Warskulat U, Flogel $\mathrm{CH}$, Jacoby HG, Hartwig M, Thewissen MW, Merx AL, et all. Taurine transporter knockout depletes muscle taurine levels and results in severe skeletal muscle impairment but leaves cardiac function uncompromised. Amino Acids 2004; 18: 577-9. DOI:10.1096/fj.030496fje

30.CMH A , Howard A, Walters J, Ganapathy VV, Thwaites DT. Taurine uptake across the human intestinal brush border membrane is via two transporters H+-coupled PAT1 SLC36A1 and Na+- and Cl--dependent TauT SLC6A6. J Physiol 2009; 587:731-44.

DOI: $10.1113 /$ jphysiol.2008.164228 


\title{
Efficacy of Taurine Supplementation on Markers of Atherothrombosis and Atherogenesis Following Exercise Protocol Bruce Modified in Elderly Men with Myocardial Infarction
}

\author{
Dabidi Roshan $V^{1^{*}}$, Afshan $S^{l}$, Aslani $E^{2}$
}

(Received: July 9, 2016

Accepted: January 18, 2017)

\begin{abstract}
Introduction: Myocardial infarction (MI) is a leading cause of morbidity and mortality. Taurine, an essential amino acid, plays a critical role in cardiovascular function. The present study was accomplished to investigate the beneficial role of taurine on atherogenesis and atherothrombosis indexes in patients with MI.
\end{abstract}

Materials \& Methods: In this semiexperimental study, 16 cases, 50 to 60 years old suffering from myocardial infarction were randomly classified into two experimental (taurine supplement) and placebo groups. The subjects of the experimental group took 3 supplement capsules containing $500 \mathrm{mg}$ of taurine before the 3 daily meals. The placebo group took 3 capsules containing starch, at the same time as the experimental members. Plasma blood sampling was carried out on the subjects at baseline level and after the modified Bruce protocol with and without taurine supplements or placebo in the same conditions.
Findings: There were no statistically significant differences in the general data, such as age, weight, BMI and Vo2max between the taurine supplement group and the control $(\mathrm{P}<0.05)$ Taurine supplementation caused significant decrease in the LDL-C/HDL-C ، TC/HDL$\mathrm{C}$ ،TG/HDL-C and Plate/HDL-C ratios in the supplementation and placebo groups at baseline level as well as after exhaustive exercise with modified Bruce protocol.

\section{Discussion \& Conclusion: Our investigation results confirm the significance of dietary intervention in patients with MI. Taurine may be an essential candidate to enrich nutrition supports for critically ill patients, although more researches seem necessary to get at a conclusive consideration.}

Keywords: taurine supplementation, atherogenic, atherothrombosis, myocardial infarction

\footnotetext{
1. Department of Sport Physiology, Faculty of Sport Sciences, University of Mazandaran, Babolsar, Iran

2. Department of Sport Physiology, Sari Branch, Islamic Azad University, Iran

*Corresponding author Email: vdabidiroshan@yahoo.com
} 